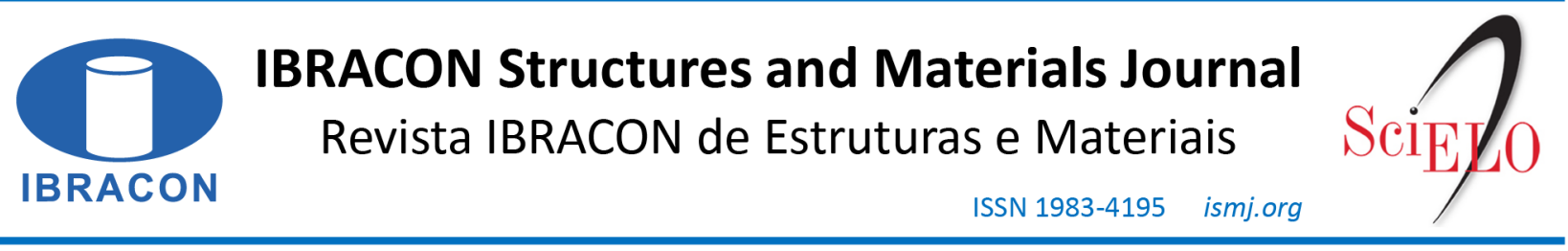

ORIGINAL ARTICLE

\title{
Influence of concrete strength, fiber content and aspect ratio in the residual flexural strength of steel fiber reinforced self- compacting concrete
}

\author{
Influência da resistência à compressão do concreto, teor de fibra e fator de forma \\ das fibras, na resistência residual do concreto autoadensável reforçado com fibra \\ de aço
}

\author{
Matheus Galvão Cardoso ${ }^{\mathrm{a}}$ \\ Rodrigo de Melo Lameiras ${ }^{\mathrm{a}}$ (D) \\ Valdirene Maria Silva Capuzzo ${ }^{\mathrm{a}}$
}

${ }^{a}$ Universidade de Brasília - UnB, Departamento de Engenharia Civil e Ambiental - ENC, Brasília, DF, Brasil

Received 05 March 2020

Accepted 08 November 2020

\begin{abstract}
Steel Fiber Reinforced Self-Compacting Concrete (SFRSCC) is a material that combines the benefits of self-compacting concrete in the fresh state and the greater durability, with the gains of fiberreinforced concrete in the hardened state, especially the gains in residual flexural strength. Results are presented in this paper of residual flexural strengths on 48 prenotched prisms conducted in accordance with RILEM TC 162 TDF for the Steel Fiber Reinforced Self-Compacting Concretes (SFRSCC). This article presents equations to estimate residual flexural stresses in SFRSCC. For this, SFRSCC prisms of two compressive strength classes, $20 \mathrm{MPa}$ and $40 \mathrm{MPa}$, were produced with 3 different types of steel fibers with the contents volume of $0.5 \%$ and $1.0 \%$. Based on the test results, equations were proposed to determine the residual flexural stresses established through regression analysis, which were, then, further validated with concretes produced in this work and results available in the literature. The equations found, despite showing an indication of the residual flexural strengths that will be achieved, obtained a relatively high error. In order for the equations to be applied in a technical way, further studies for a larger sample need to be carried out, seeking to optimize the equations.
\end{abstract}

Keywords: steel fiber reinforced self-compacting concrete (SFRSCC), flexural residual strength, three point bending test, hooked end fiber.

Resumo: O concreto autoadensável reforçado com fibra de aço (CAARF) é um material que combina os benefícios do concreto autoadensável no estado fresco e a maior durabilidade, com os ganhos do concreto reforçado com fibras no estado endurecido, principalmente os ganhos quanto as resistências residuais à flexão. São apresentados neste trabalho os resultados de ensaios das resistências residuais à flexão de 48 prismas entalhados, conduzidos de acordo com RILEM TC 162 TDF para concreto autoadensável reforçado com fibra de aço (CAARF). Este artigo propõe equações para estimar as resistências residuais à flexão nos CAARFs. Para isso, prismas de CAARFs de duas classes de resistência à compressão, $20 \mathrm{MPa}$ e $40 \mathrm{MPa}$, foram produzidos com 3 tipos diferentes de fibras de aço com o teor de $0,5 \%$ e 1,0\% em relação ao volume de concreto. A partir dos resultados dos ensaios, foram propostas equações para determinar as tensões de flexão residuais estabelecidas por meio de análise de regressão, as quais foram, então, validadas com os concretos produzidos neste trabalho e resultados disponíveis na literatura. As equações encontradas, apesar de mostrarem uma indicação das resistências à flexão residuais que serão alcançadas, obtiveram um erro relativamente alto. Para que as equações possam ser aplicadas de forma técnica, novos estudos para uma amostra maior precisam ser realizados, visando otimizar as equações.

Palavras-chave: concreto autoadensável reforçado com fibra de aço, tensões residuais de flexão, ensaio de flexão a três pontos, fibra com gancho na ponta.

Corresponding author: Matheus Galvão Cardoso. E-mail: matheus-ssdo@hotmail.com

Financial support: The authors gratefully acknowledge the financial support from the FAP-DF and CNPq.

Conflict of interest: Nothing to declare. 
How to cite: M. G. Cardoso, R. M. Lameiras, and V. M. S. Capuzzo, "Influence of concrete strength, fiber content and aspect ratio in the residual flexural strength of steel fiber reinforced self-compacting concrete," Rev. IBRACON Estrut. Mater., vol. 14, no. 5, e14503, 2021, https://doi.org/10.1590/S1983-41952021000500003

\section{INTRODUCTION}

The Steel Fiber Reinforced Self-Compacting Concrete (SFRSCC) is an material that combines the benefits of fiber reinforced concrete such as tenacity gain and the ability to withstand residual post-cracking tensile stresses, with the characteristics of self-compacting concrete, such as workability, and the ability to fill and to overcome restrictions without segregating, which eliminates the use of vibration during casting. Several researches has already shown that SFRSCC can be used in segments of tunnels, precast roof elements, beams, sandwich panels, sheet piles, floors and slabs [1]-[7].

The great differential of SFRSCC is related to its residual post cracking flexural strength. A barrier found in the production of SFRSCC is the difficulty in pre-defining the desired post-cracking behavior when determining concrete mixtures. Although there are already some studies that try to determine the influence of fiber volume and its characteristics such as fiber type and compressive strength [8]-[14] in the post-cracking behavior of concrete, the dosage of SFRSCC has been performed, in most times, empirically. The determination of equations that correlate the residual flexural strengths of SFRSCC with the characteristics of concrete and fiber would allow an optimized dosage of this material.

Recently, Domski and Katzer [14] proposed equations to estimate residual strength for common concretes, using the geometric characteristics of the fibers and fiber volume as variables. However, has been verified in some research the great influence of the compressive strength of the matrix on the residual strengths [8], [12], [13].

This work determined new equations to estimate the residual strengths of SFRSCC, inserting the geometric characteristics, the fiber volume content and the compressive strength the matrix as input variables. The determination of equations that allow the estimating residual strength based on the materials used for the production of the SFRSCC can contribute to increase the use of this concrete, considering it will make it possible to perform more rational mixture of this material.

\section{MATERIALS AND EXPERIMENTAL PROGRAM}

The experimental program, carried out at the Laboratories of the Materials and Structures of the University of Brasília, included a total of 48 SFRSCC prisms for 3 point bending tests on prenotched specimens, conducted in accordance with EN 14651 [15]. The materials used in this research were Portland Cement CP II $32 \mathrm{~F}$, a river sand with a maximum diameter of $2.36 \mathrm{~mm}$, a coarse aggregate with a maximum diameter of $9.5 \mathrm{~mm}$, a limestone filler, a superplasticizer admixture (Master Glenium 51) and three types of steel fibers with hooked end.

\subsection{Steel fibers}

Three types of steel fibers with hooked end were used as reinforcement. The properties of the used fibers, according to their manufactures, are presented in Table 1.

Table 1.Physical characteristics of the fibers used in the research.

\begin{tabular}{cccccc}
\hline Fiber Type & Diameter $\boldsymbol{d}_{\boldsymbol{f}}(\mathbf{m m})$ & Length $\boldsymbol{l}_{\boldsymbol{f}}(\mathbf{m m})$ & Aspect ratio $\boldsymbol{l}_{\boldsymbol{f}} \boldsymbol{d}_{\boldsymbol{f}}$ & $\begin{array}{c}\text { Nominal Young's } \\
\text { modulus (MPa) }\end{array}$ & $\begin{array}{c}\text { Nominal unit } \\
\text { weight }\left(\mathbf{K g} / \mathbf{m}^{\mathbf{3}}\right)\end{array}$ \\
\hline $\mathrm{ST}-33 / 44$ & 0.75 & 33 & 44 & 210 & 7850 \\
\hline $\mathrm{ST}-33 / 60$ & 0.55 & 33 & 60 & 210 & 7850 \\
\hline $\mathrm{ST}-50 / 67$ & 0.75 & 50 & 67 & 210 & 7850 \\
\hline
\end{tabular}

\subsection{Concrete Mixture}

The tests were performed with twelve distinct concrete mixes. The mixes were obtained using the software Betonlab Pro 3, following recommendations proposed by De Larrard and Sedran [16]. They were produced with compressive strength classes equal to $20 \mathrm{MPa}$ and $40 \mathrm{MPa}$ for each fiber. The fiber contents used were $0.5 \%$ and $1.0 \%$ in relation to the SFRSCC volume (Table 2).

The flow spread of concretes in the fresh state was registered following the recommendations of NBR 15823 [17]. The average value obtained for the flow spread of SFRSCC was equal to $650 \mathrm{~mm}$. 
Table 2 . Mixes of the SFRSCC produced.

\begin{tabular}{|c|c|c|c|c|c|c|c|c|c|c|c|c|c|c|}
\hline \multirow{3}{*}{$\begin{array}{c}\text { Mixtures } \\
\text { Fiber Volume (\%) }\end{array}$} & \multicolumn{7}{|c|}{20 MPa } & \multicolumn{7}{|c|}{$40 \mathrm{MPa}$} \\
\hline & \multirow{2}{*}{$\frac{\text { REF }}{0.00}$} & \multicolumn{2}{|c|}{ ST-33/60 } & \multicolumn{2}{|c|}{ ST-50/67 } & \multicolumn{2}{|c|}{ ST-33/44 } & \multirow{2}{*}{$\frac{\text { REF }}{0.00}$} & \multicolumn{2}{|c|}{ ST-33/60 } & \multicolumn{2}{|c|}{ ST-50/67 } & \multicolumn{2}{|c|}{ ST-33/44 } \\
\hline & & 0.50 & 1.00 & 0.50 & 1.00 & 0.50 & 1.00 & & 0.50 & 1.00 & 0.50 & 1.00 & 0.50 & 1.00 \\
\hline Coarse aggregate $(\mathrm{G})\left(\mathrm{kg} / \mathrm{m}^{3}\right)$ & 852 & 844 & 826 & 834 & 802 & 826 & 804 & 852 & 844 & 805 & 834 & 806 & 826 & 803 \\
\hline Sand $(\mathrm{S})\left(\mathrm{kg} / \mathrm{m}^{3}\right)$ & 633 & 627 & 614 & 619 & 596 & 613 & 597 & 633 & 649 & 600 & 641 & 599 & 635 & 597 \\
\hline Cement $(\mathrm{C})\left(\mathrm{kg} / \mathrm{m}^{3}\right)$ & 378 & 382 & 392 & 388 & 398 & 392 & 393 & 498 & 505 & 515 & 513 & 515 & 519 & 520 \\
\hline Limestone Filler $\left(\mathrm{kg} / \mathrm{m}^{3}\right)$ & 242 & 244 & 252 & 249 & 281 & 252 & 287 & 133 & 134 & 177 & 137 & 180 & 138 & 173 \\
\hline Superplasticizer $(\mathrm{SP})\left(\mathrm{kg} / \mathrm{m}^{3}\right)$ & 3.90 & 5.00 & 5.20 & 4.10 & 4.00 & 5.20 & 5.50 & 5.10 & 5.30 & 6.10 & 6.50 & 6.10 & 6.60 & 5.20 \\
\hline Water $(\mathrm{W})\left(\mathrm{kg} / \mathrm{m}^{3}\right)$ & 231 & 234 & 240 & 237 & 244 & 240 & 240 & 231 & 234 & 238 & 237 & 238 & 240 & 241 \\
\hline
\end{tabular}

\subsection{Compressive strength}

The compressive strength $\left(f_{\mathrm{cm}}\right)$ of concretes were determined with compressive tests performed on cylinders of $100 \mathrm{~mm}$ diameter and $200 \mathrm{~mm}$ height casted simultaneously with the three-point bending test specimens. These concrete cylinders were cured for 28 days under laboratory temperature, inside a chamber with humidity control. The compressive strength was obtained based on the procedures given in NBR 5739 [18].

\subsection{Three point bending test (3PBT)}

Four specimens for the three point bending test were produced for each concrete mix, with cross section of $150 \mathrm{~mm}$ $\times 150 \mathrm{~mm}$ and length of $550 \mathrm{~mm}$. These specimens are in accordance to the EN 14651 [15]. The specimens were cured for 28 days under laboratory temperature inside a chamber with humidity control. The tests were carried on a press EMIC servo-controlled hydraulic-system. The tests were controlled by the internal displacement transducer of the test machine at a rate of $0.1 \mathrm{~mm} / \mathrm{min}$. Each test lasted about 60 minutes and was interrupted when the crack opening reached $6 \mathrm{~mm}$. In the execution of this test, the load was applied in the middle of the specimens' span. The specimens were tested in a three-point bending test with a central notch $(25 \mathrm{~mm})$, as illustrated in Figure 1. The crack opening was measured using two linear variable differential transformers (LVDT), one on each of the notch's side, fixed at the base of the specimens.

The acquisition of the test data, i.e., load and crack mouth opening, was performed using a $500 \mathrm{kN}$ HBM load cell and two LVDTs. These devices were connected to a Spider 8 module (model SR30), manufactured by HBM, and controlled by the CATMAN software. This enabled continuous readings of force and displacement. With the results of the crack opening and the load it was possible to obtain the curves that relate the load to the Crack Mouth Opening Displacement (CMOD). The following parameters were calculated: proportionality limit $\left(\mathrm{f}_{\mathrm{ft}, \mathrm{L}}, \mathrm{f}\right.$ ) and residual flexural strength $\mathrm{f}_{R .1}, \mathrm{f}_{\mathrm{R} .2}, \mathrm{f}_{\mathrm{R} .3}, \mathrm{f}_{\mathrm{R} .4}$, corresponding to CMOD values equal to $0.5 \mathrm{~mm}, 1,5 \mathrm{~mm}, 2.5 \mathrm{~mm}$ and $3.5 \mathrm{~mm}$, respectively.

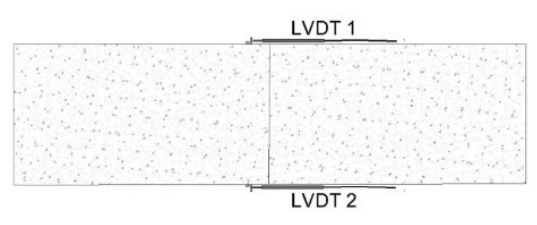

(a)

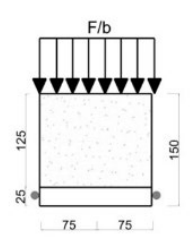

(b)

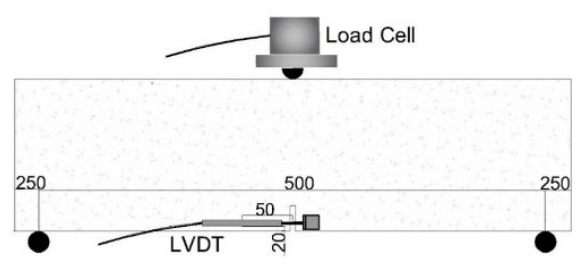

(c)

Figure 1. Three point bending test setup in accordance with RILEM TC 162 [19]; a: plan view; b: cross section of specimen; c: side view of specimen. Dimensions in $\mathrm{mm}$. 


\subsection{Determination of equations: Linear regression}

Based on the results obtained with the three-point bending and compressive strength tests and on the equations proposed by Domski and Katzer [14], a linear regression was performed using the Microsoft Excel 2013 software. Unlike Domski and Katzer [14], who only considered the volume and geometric characteristics of the fiber, the SFRSCC's compressive strength was also inserted as a variable in the equation. Another improvement of the equations found in this work is that they are applicable to self-compacting concrete. As a result, it was obtained equations which correlate the residual flexural strengths $f_{R .1}, f_{R .2}, f_{R .3}$ and $f_{R .4}$ with the compressive strength of the concrete, the geometric characteristics of the fibers and the volume of fiber adopted.

Each residual flexural strength, $f_{R .1}, f_{R .2}, f_{R .3}, f_{R .4}$, was correlated by means of an equation with the aspect ratio, fiber volume and the square root compressive strength of the concrete. Thus, coefficients were determined that, multiplied by these variables (aspect ratio, fiber volume and square root of the SFRSCC compression strength), provided the SFRSCC residual resistance response.

\section{RESULTS AND DISCUSSIONS}

\subsection{Compressive Strength}

The Figure 2 and Figure 3 show the results obtained in the SFRSCC compressive strength test. Hereinafter the specimens are identified by the following nomenclature "X-YST-Z/W", where: $\mathrm{X}$ is the nominal compressive strength, $\mathrm{Y}$ is the fiber volume and ST-Z/W is the type of fiber, where $\mathrm{Z}$ is the length and $\mathrm{W}$ is the aspect ratio of the steel fiber. $\mathrm{REF}$ is the concrete without fiber.

Despite the variations found in the different SFRSCC, there were no major changes promoted by the addition of fibers in the compressive strength of the concrete. The same was observed in the concretes produced by Hu et al. [20].

It was observed a decrease in the strength of the 20-MPa concrete when comparing the strength of the concrete with fiber to the reference concrete. However, after performing an ANOVA and Tukey statistical tests, it was verified that the compressive strength of the concrete did not change significantly.

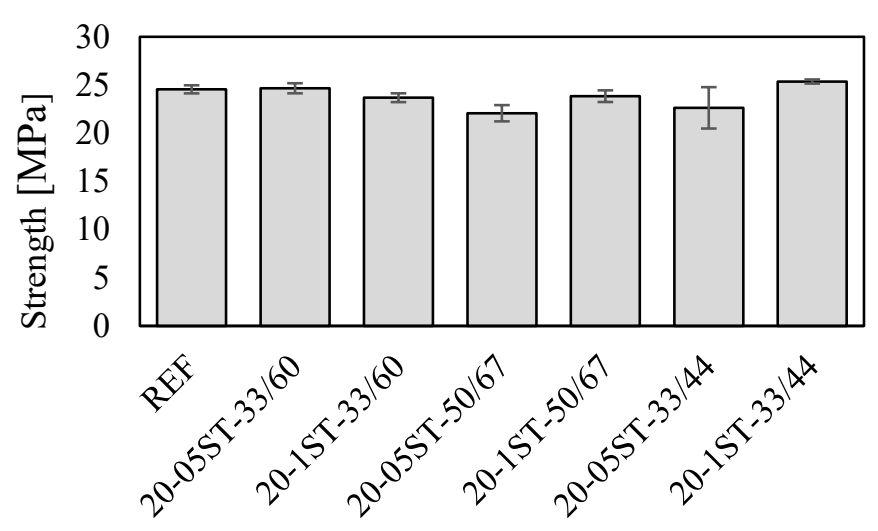

Figure 2. Compressive strength for the 20-MPa SFRSCC .

For the 40-MPa Steel Fiber Reinforced Self-Compacting Concretes, shown in Figure 3, it was observed that some mixtures presented a higher strength than that of the reference concrete. This can be explained by the higher cement consumption of these mixes. In the concretes with ST-33/44 fiber, a more evident reduction in compressive strength was observed when compared to other concretes, especially in the case of $1.0 \%$ fiber content . After performing an ANOVA and Tukey tests it was found that in the case of the 40-MPa SFRSCC, there was a significant variation in the compressive strength of concrete when fibers were present. The decrease in the strength of concretes using the ST-33/44 fiber can be explained by differences in SFRC mixtures and by its greater tendency to agglomerate. 


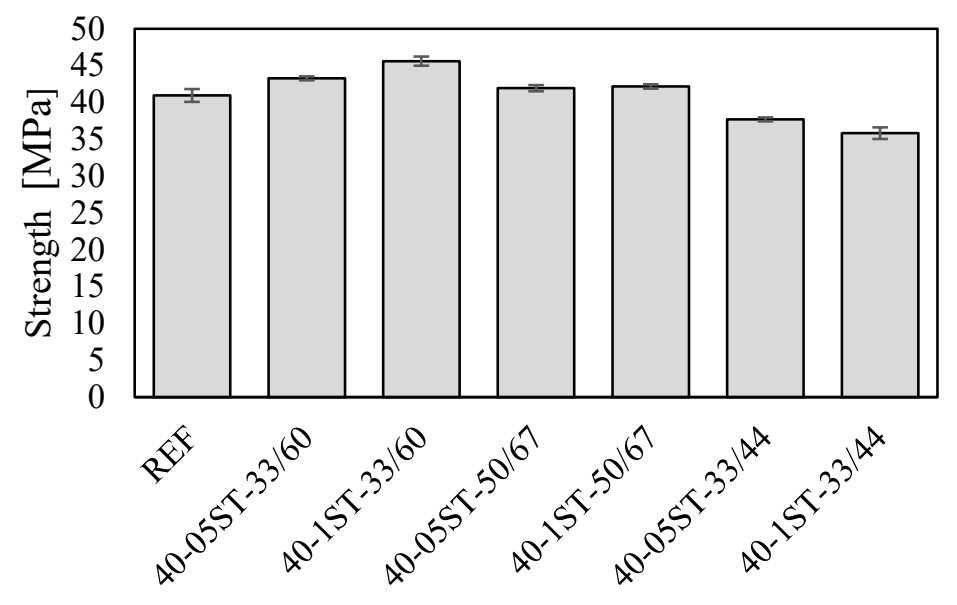

Figure 3. Compressive strength for the 40-MPa SFRSCC .

\subsection{Three point bending tests results}

In the three point bending tests in most specimens, a single crack was observed in the rupture, especially in concretes with a smaller fiber volume. Some specimens, in which the fibers offered less reinforcement to the concrete, this crack was almost vertical, as can be seen in Figure 4a. In some isolated cases, the appearance of multiple cracks in the region of application of the load was observed, as can be seen in Figure $4 \mathrm{~b}$.

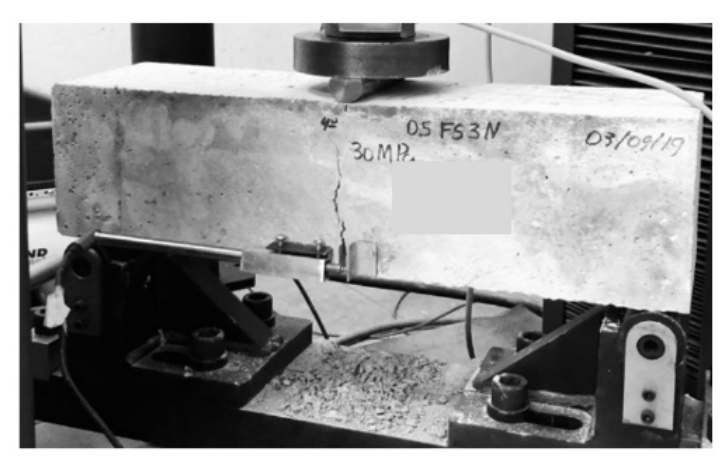

(a)

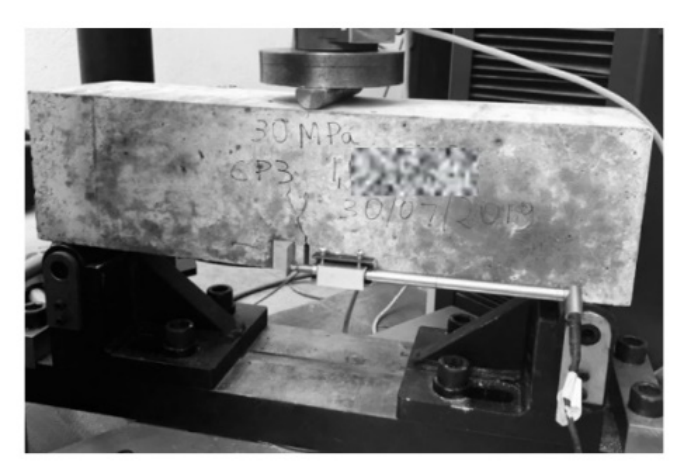

(b)

Figure 4. Failure mechanisms in specimens of three point bending tests, a: only vertical crack; b: multiple cracks

The average of the load values obtained in the three point bending test, and the envelope formed by the highest and lowest values found, versus CMOD curves are illustrated in Figure 5, Figure 6 and Figure 7. Table 3 shows the parameters that characterize the concrete's post-cracking behavior, showing the mean value and the coefficient of variation found between the samples. It is possible to observe in Figure 5, Figure 6, Figure 7 a significant dispersion of the results, which is common for this type of concrete in view of the impossibility of ensuring that the fibers equally distributed and oriented. This fact was also observed in other studies carried out with concrete reinforced with fibers [19], [21]-[23].

For SFRSCC with ST-33/60 fiber, it was possible to observe that there was a less significant variation between the values found, according to the ANOVA test. The envelope of the results obtained in the four samples of each concrete showed less dispersion from the average. This can be explained by the fact that the concretes produced with this fiber presented more homogeneous properties in the fresh state.

The Figure 5 show the Experimental Load vs. CMOD relationships for SFRSCC with the ST-33/60 fiber. 


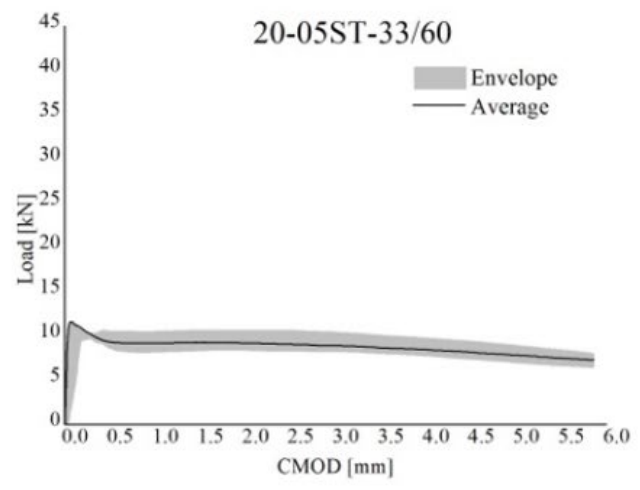

(a)

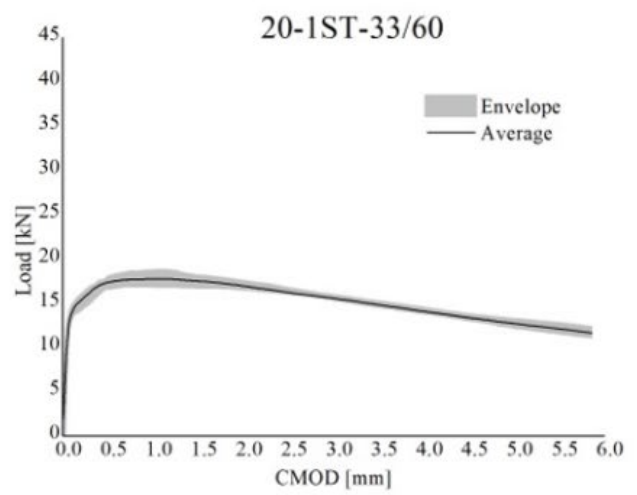

(c)

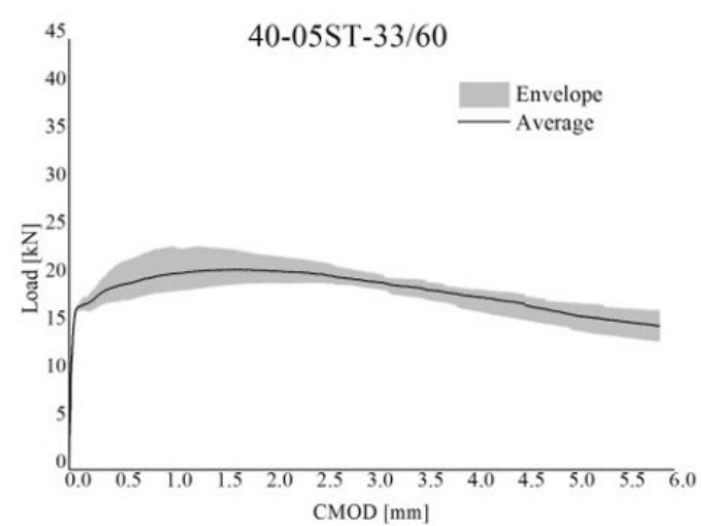

(b)

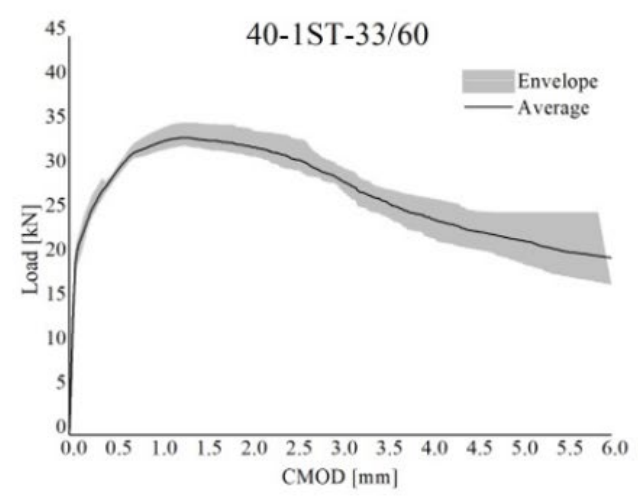

(d)

Figure 5. Experimental Load vs. CMOD relationships for SFRSCC with the ST-33/60 fiber: (a)20-05ST-33/60; (b) 40-05-ST33/60; (c) 20-1ST-33/60; (d) 40-1ST-33/60.

The Tukey test showed a significant difference between the residual resistances for concretes with the same compressive strength, with varying the fiber content from $0.50 \%$ to $1.00 \%$. When the fiber content was fixed and the compressive strength varied from $20 \mathrm{MPa}$ to $40 \mathrm{MPa}$, there was a significant increase in the residual resistances obtained, as also shown by the Tukey test.

In the 20-05ST-33/60 and 20-1ST-33/60 concretes, as can be seen in Figure 5a and Figure $5 \mathrm{c}$ and Table 3, it is possible to observe the increase in residual strengths achieved with the addition of fibers. With the increase in fiber content from $0.5 \%$ to $1.0 \%$, an increase of $87.25 \%$ in the values of $\mathrm{f}_{\mathrm{R} .1}$ was observed, rising from $3.06 \mathrm{MPa}$ to 5.73 $\mathrm{MPa}$, and an increase of $67.88 \%$ in $\mathrm{f}_{\mathrm{R} .3}$, which rose from $3.02 \mathrm{MPa}$ to $5.07 \mathrm{MPa}$. The same was seen in the concretes 40-05ST-33/60 and 40-1ST-33/60 illustrated in Figure 5b and Figure 5d and in Table 3, in which the $\mathrm{f}_{\mathrm{R} .1}$ increased from 6.17 MPa to 9.42 MPa, resulting in an increase of $52.67 \%$, and the $f_{R .3}$ increased from $6.54 \mathrm{MPa}$ to $9.96 \mathrm{MPa}$, which represents an increase of $52.29 \%$.

In concretes with the same fiber content, it is possible to observe the impact of the compressive strength in increasing the toughness of the concrete, as can be seen when comparing Figure 5a and Figure $5 \mathrm{~b}$ and the results of Table 3. Comparing the post-cracking behavior of $20-05$ ST-33/60 to $40-05$ ST-33/60, there was an increase of $101.63 \%$ in the $f_{R .1}$, while the $f_{R .3}$ increased $116.56 \%$. The same can be seen between the concretes $20-1 \mathrm{ST}-33 / 60$ and $40-1 \mathrm{ST}-33 / 60$, in which the $f_{R .1}$ and the $f_{R .3}$ an increase of $64.40 \%$ and $96.45 \%$, respectively.

The Figure 6 show experimental load vs. CMOD relationships for SFRSCC with the ST-50/67 fiber. 


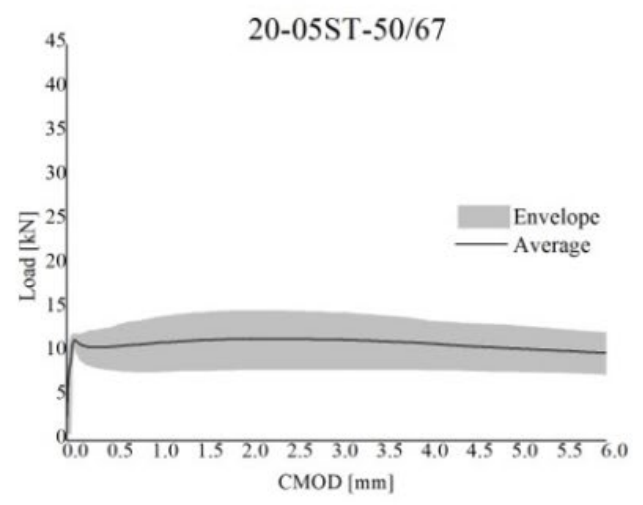

(a)

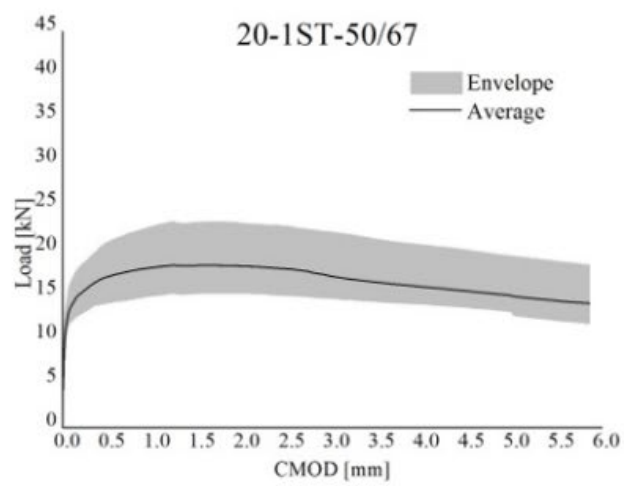

(c)

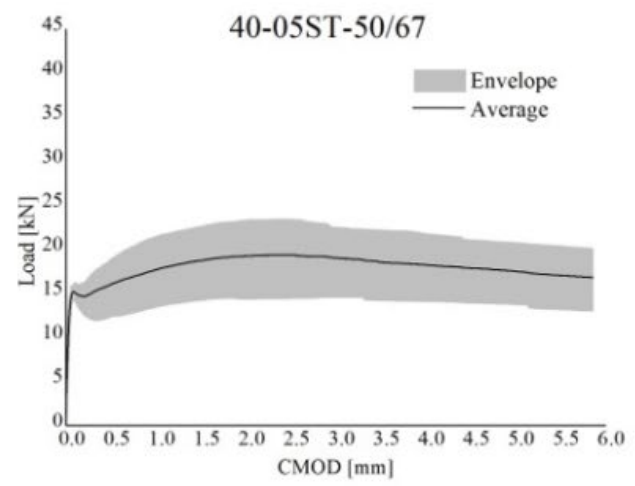

(b)

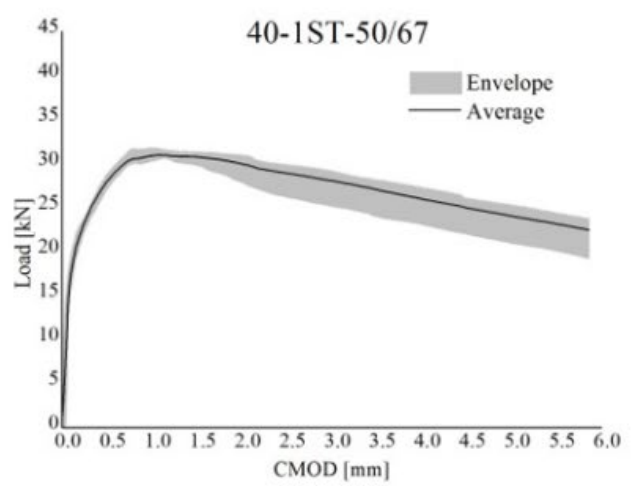

(d)

Figure 6. Experimental Load vs. CMOD relationships for SFRSCC with the ST-50/67 fiber: (a) 20-05ST-50/67; (b) 40-05-ST50/67; (c) 20-1ST-50/67; (d) 40-1ST-50/67.

Comparing the $20 \mathrm{MPa}$ concretes with ST-50/67 fibers, shown in Figure 6a and in Figure 6c, the same behavior can be observed, with the addition of fibers resulting in a significant increase in post-cracking strength. The $f_{R .1}$ increased from 3.69 MPa to 5.48 MPa, which is an increase of $48.51 \%$, and the $\mathrm{f}_{\mathrm{R} .3}$, from $4.05 \mathrm{MPa}$ to $5.77 \mathrm{MPa}$, which is an increase of $42.47 \%$. For concretes with compressive strength equal to $40 \mathrm{MPa}$, the $\mathrm{f}_{R .1}$ e $\mathrm{f}_{\mathrm{R} .3}$ increased $62.14 \%$ and $37.30 \%$ when the fiber content increased from $0.5 \%$ to $1.0 \%$, respectively. Comparing the concretes with the same fiber content, varying the compressive strength of the concrete from $20 \mathrm{MPa}$ to $40 \mathrm{MPa}$ for the ST-50/67 fiber, when the fiber volume used was $0.5 \%$, led to a significant gain in the $\mathrm{f}_{\mathrm{R} .1}$ e $\mathrm{f}_{\mathrm{R} .3}, 49.69 \%$ and $66.17 \%$ respectively. A similar trend, but even more significantly, was verified by comparing the concretes with the resistances with levels of $1.0 \%$ of this fiber, where the $f_{R .1}$ e $f_{R .3}$ grew $63.32 \%$ and $72.62 \%$. Venkateshwaran et al. [12] found a direct relationship between the fiber reinforcement capacity and the matrix strength, as the fiber anchoring capacity offered by the concrete matrix is essential for the fibers to be mechanically activated.

The Figure 7 show experimental load vs. CMOD relationships for SFRSCC with the ST-33/44 fiber.

For the ST-33/44 fiber, the variation of the content from $0.5 \%$ to $1.0 \%$ in the $20 \mathrm{MPa}$ concrete, as can be seen in Figure $7 \mathrm{a}$ and Figure $7 \mathrm{c}$ and Table 3, resulted in an increase in $\mathrm{f}_{\mathrm{R} .1}$ from $2.72 \mathrm{MPa}$ to $4.74 \mathrm{MPa}$ and fR.3 from $2.81 \mathrm{MPa}$ to $4.77 \mathrm{MPa}$, which represents an increase of $74.26 \%$ and $69.75 \%$ respectively. In the comparison between $40 \mathrm{MPa}$ concretes with this fiber, shown in Figure $5 b$ and Figure $5 d$, the $f_{R .1}$ increase of $59,01 \%$ and the $f_{R .3}$ increase of $58,40 \%$. 


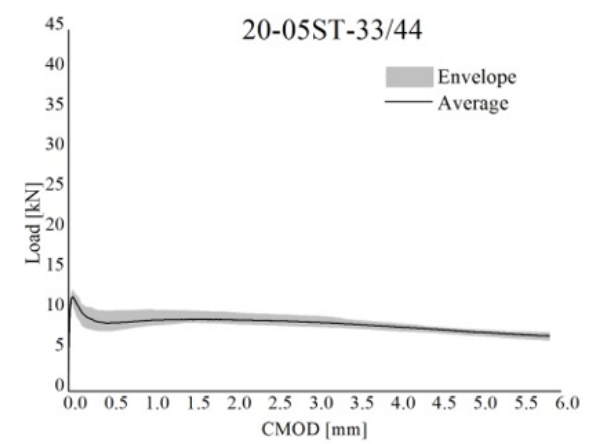

(a)

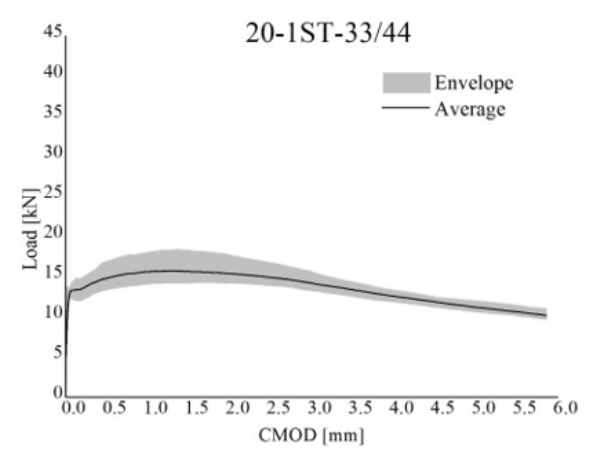

(c)

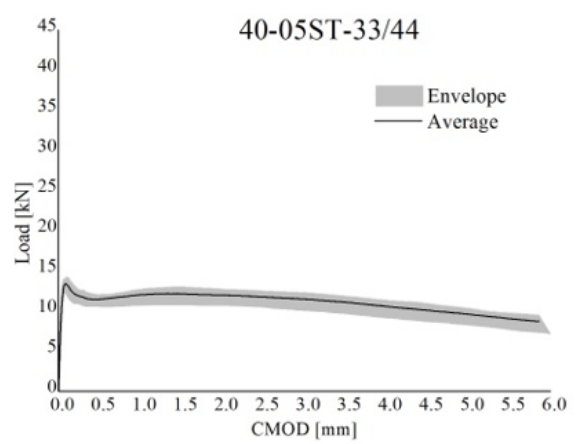

(b)

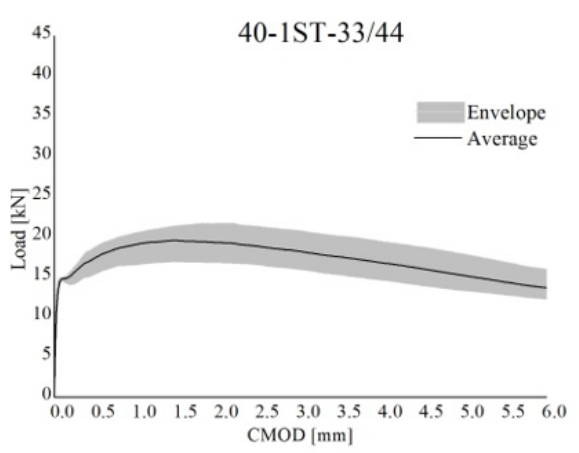

(d)

Figure 7. Experimental Load vs. CMOD relationships for SFRSCC with the ST-33/44 fiber: (a)20-05ST-33/44; (b) 40-05-ST33/44; (c) 20-1ST-33/44; (d) 40-1ST-33/44

In concretes with this fiber, when the comparison is made for the same fiber contents and varying the compressive strength of the concrete from $20 \mathrm{MPa}$ to $40 \mathrm{MPa}$, there were increases in $\mathrm{f}_{\mathrm{R} .1}$ and in $\mathrm{f}_{\mathrm{R} .3}$, of $34.56 \%$ and $33.45 \%$ respectively for a $0.5 \%$ fiber volume content. In the case of concretes with $1.0 \%$ of this fiber, $f_{R .1}$ e $f_{R .3}$ increased $22.78 \%$ and $24.53 \%$ respectively.

When comparing the ST-33/44 and ST 33/60 fibers, despite having the same length, the ST-33/60 fiber guaranteed higher values of residual resistance to concretes due to their higher aspect ratio. The same was observed by Abbass et al. [24], who found that among concretes with the same compressive strength and fibers of the same length, the aspect ratio will have an impact on the residual flexural strength values achieved. Higher aspect ratios contribute to higher residual flexural strength values.

After comparing the SFRSCC produced with the three types of fiber and performing an analysis of variance and a Tukey test, it was found that the concretes produced with the ST-50/67 fiber and the ST-33/60 fiber, despite the physical differences between the two fibers, showed significantly equal results in residual strength. This was observed for the same fiber contents and equal strength values. Showing the great importance of the aspect ratio of the fibers. These two fibers, despite the differences between their lengths and diameters, have very similar aspect ratios (60 and 67 respectively).

An ANOVA and a Tukey test were performed on the results obtained for concretes produced with the ST-33/44 fiber and for the results obtained for the concretes produced with the ST-50/67 and ST-33/60 fibers. Residual resistances were significantly different. This can be explained by the great difference between the aspect ratios, between the ST 33/44 fiber and the ST-50/67 and ST-33/60 fibers. Chu and Kwan [25] also found that for concrete reinforced with steel fibers that have a higher aspect ratio, the residual strengths obtained were higher. 
Table 3. Residual flexural strength of the concretes determined in the three point bending tests.

\begin{tabular}{|c|c|c|c|c|c|c|c|}
\hline \multirow{2}{*}{ Concrete mix } & & \multirow{2}{*}{$\mathbf{f}_{\mathrm{fct}, \mathrm{L}}[\mathbf{M P a}]$} & \multirow{2}{*}{ 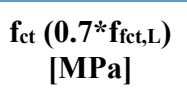 } & \multicolumn{4}{|c|}{ Residual Flexural Strength } \\
\hline & & & & $\mathbf{f}_{\mathrm{R} .1}[\mathrm{MPa}]$ & $\mathbf{f}_{\mathrm{R} .2}$ [MPa] & $\mathbf{f}_{\mathrm{R} .3}[\mathrm{MPa}]$ & $\mathbf{f}_{\mathrm{R} .4}$ [MPa] \\
\hline \multirow[t]{2}{*}{$20-05 \mathrm{ST}-50 / 67$} & Avg. & 3.68 & 2.58 & 3.69 & 4.01 & 4.05 & 3.95 \\
\hline & $\mathrm{CoV}$ & $4.4 \%$ & $4.4 \%$ & $20.1 \%$ & $24.3 \%$ & $24.0 \%$ & $23.3 \%$ \\
\hline \multirow[t]{2}{*}{$20-1 \mathrm{ST}-50 / 67$} & Avg. & 3.97 & 2.78 & 5.48 & 5.89 & 5.77 & 5.28 \\
\hline & $\mathrm{CoV}$ & $14.8 \%$ & $14.8 \%$ & $18.9 \%$ & $20.1 \%$ & $18.2 \%$ & $19.4 \%$ \\
\hline \multirow[t]{2}{*}{$20-05 \mathrm{ST}-33 / 60$} & Avg. & 3.07 & 2.15 & 3.06 & 3.07 & 3.02 & 2.86 \\
\hline & $\mathrm{CoV}$ & $16.9 \%$ & $16.9 \%$ & $8.5 \%$ & $10.5 \%$ & $10.8 \%$ & $9.8 \%$ \\
\hline \multirow[t]{2}{*}{$20-1 \mathrm{ST}-33 / 60$} & Avg. & 3.92 & 2.75 & 5.73 & 5.58 & 5.07 & 4.57 \\
\hline & $\mathrm{CoV}$ & $10.4 \%$ & $10.4 \%$ & $4.4 \%$ & $4.9 \%$ & $5.7 \%$ & $7.8 \%$ \\
\hline \multirow[t]{2}{*}{ 20-05ST-33/44 } & Avg. & 3.76 & 2.63 & 2.72 & 2.86 & 2.81 & 2.66 \\
\hline & $\mathrm{CoV}$ & $8.1 \%$ & $8.1 \%$ & $12.6 \%$ & $8.1 \%$ & $6.6 \%$ & $5.1 \%$ \\
\hline \multirow[t]{2}{*}{ 20-1ST-33/44 } & Avg. & 4.17 & 2.92 & 4.74 & 5.01 & 4.77 & 4.28 \\
\hline & $\mathrm{CoV}$ & $6.6 \%$ & $6.6 \%$ & $10.3 \%$ & $11.6 \%$ & $8.6 \%$ & $5.8 \%$ \\
\hline \multirow[t]{2}{*}{$40-05 \mathrm{ST}-50 / 67$} & Avg. & 4.87 & 3.41 & 5.52 & 6.48 & 6.73 & 6.40 \\
\hline & $\mathrm{CoV}$ & $3.9 \%$ & $3.9 \%$ & $9.6 \%$ & $11.2 \%$ & $10.8 \%$ & $10.0 \%$ \\
\hline \multirow[t]{2}{*}{ 40-1ST-50/67 } & Avg. & 4.07 & 2.85 & 8.95 & 9.84 & 9.24 & 8.65 \\
\hline & $\mathrm{CoV}$ & $37.7 \%$ & $37.7 \%$ & $2.9 \%$ & $2.3 \%$ & $6.3 \%$ & $7.6 \%$ \\
\hline \multirow[t]{2}{*}{$40-05 \mathrm{ST}-33 / 60$} & Avg. & 5.17 & 3.62 & 6.17 & 6.68 & 6.54 & 6.06 \\
\hline & $\mathrm{CoV}$ & $2.4 \%$ & $2.4 \%$ & $9.0 \%$ & $7.9 \%$ & $4.7 \%$ & $4.1 \%$ \\
\hline \multirow[t]{2}{*}{ 40-1ST-33/60 } & Avg. & 5.28 & 3.69 & 9.42 & 10.66 & 9.96 & 8.44 \\
\hline & $\mathrm{CoV}$ & $10.7 \%$ & $10.7 \%$ & $1.6 \%$ & $3.9 \%$ & $5.2 \%$ & $4.8 \%$ \\
\hline \multirow[t]{2}{*}{$40-05 \mathrm{ST}-33 / 44$} & Avg. & 4.10 & 2.87 & 3.66 & 3.88 & 3.75 & 3.54 \\
\hline & $\mathrm{CoV}$ & $6.1 \%$ & $6.1 \%$ & $5.6 \%$ & $8.3 \%$ & $7.8 \%$ & $9.0 \%$ \\
\hline \multirow[t]{2}{*}{ 40-1ST-33/44 } & Avg. & 4.41 & 3.08 & 5.82 & 6.31 & 5.94 & 5.46 \\
\hline & $\mathrm{CoV}$ & $6.2 \%$ & $6.2 \%$ & $3.6 \%$ & $7.9 \%$ & $12.5 \%$ & $15.2 \%$ \\
\hline
\end{tabular}

$\mathrm{f}_{\mathrm{R} .1}, \mathrm{f}_{\mathrm{R} .2}, \mathrm{f}_{\mathrm{R} .3}, \mathrm{f}_{\mathrm{R} .4}$ : are the residual flexural strength referring to the crack openings of $0.5 \mathrm{~mm}, 1.5 \mathrm{~mm}, 2.5 \mathrm{~mm}$ and $3.5 \mathrm{~mm}$, respectively; Avg: average of the values of the 4 specimens; $\mathrm{CoV}$ : covariance of the values of the 4 specimens.

\subsection{Determination of equations}

Based on the database of tests performed for the SFRSCC of this work and inspired by the equations of Domski and Katzer [14], new equations were created to estimate the residual flexural strength of self-compacting concrete reinforced with steel fibers, using the Microsoft Excel software.

Equations 1, 2, 3 and 4 represent the residual strengths $f_{R .1}, f_{R .2}, f_{R .3}, f_{R .4}$, which characterize the post-cracking behavior of SFRSCC. These were adjusted with an $\mathrm{R}^{2}$ of $0.91,0.93,0.94$ and 0,89 , respectively. Although $\mathrm{R}^{2}$ did not present such a high value, this fact is common in the measurement of phenomena with dispersed results, as is the case of SFRSCCs.

$f_{R I}=-0.59+0.07\left(\frac{l}{d}\right)+5,31\left(V_{f}\right)+1.44\left(f_{c}\right)^{0.5}$

$f_{R 2}=-13.10+0.08\left(\frac{l}{d}\right)+5.65\left(V_{f}\right)+1.81\left(f_{c}\right)^{0.5}$

$f_{R 3}=-12.33+0.08\left(\frac{l}{d}\right)+4.79\left(V_{f}\right)+1.74\left(f_{c}\right)^{0.5}$ 
$f_{R 4}=-10.70+0.08\left(\frac{l}{d}\right)+3.93\left(V_{f}\right)+1.51\left(f_{c}\right)^{0.5}$

In which:

$f_{R .1} . f_{R .2} . f_{R .3} . f_{R .4}$ are the residual flexural strength referring to the crack openings of $0.5 \mathrm{~mm}, 1.5 \mathrm{~mm}, 2.5 \mathrm{~mm}$ and $3.5 \mathrm{~mm}$, respectively;

$l:$ is the length of the fiber;

$d:$ : the fiber diameter;

$V_{f:}:$ is the volume of fiber;

$f_{c}:$ is the concrete compressive strength.

A comparison between the values predicted by the proposed equations and the values experimentally obtained are shown in Table 4.

Table 4. Comparison between the values of residual flexural strengths obtained experimentally and the values predicted by the equations.

\begin{tabular}{|c|c|c|c|c|c|c|c|c|c|}
\hline \multirow{2}{*}{\multicolumn{2}{|c|}{ Concrete Mix }} & \multicolumn{8}{|c|}{ Experimentally obtained $v$ s. predicted by the equation } \\
\hline & & \multirow{3}{*}{$\begin{array}{c}\mathbf{f}_{\mathrm{R} .1}[\mathbf{M P a}] \\
3.69 \\
3.65\end{array}$} & \multirow{3}{*}{$\begin{array}{c}\mathbf{f}_{\mathbf{R} .2} \text { [MPa] } \\
4.01 \\
3.77\end{array}$} & \multirow{3}{*}{$\begin{array}{c}\mathbf{f}_{\mathbf{R} .3} \text { [MPa] } \\
4.05 \\
3.80\end{array}$} & \multirow{2}{*}{$\begin{array}{c}\mathbf{f}_{\mathbf{R} .4}[\mathbf{M P a}] \\
3.95\end{array}$} & \multirow{3}{*}{$\begin{array}{c}\text { Error } \mathbf{f}_{\mathbf{R} .1} \\
1.13 \%\end{array}$} & \multirow{3}{*}{$\begin{array}{c}\text { Error } \mathbf{f}_{R .2} \\
6.53 \%\end{array}$} & \multirow{3}{*}{$\begin{array}{c}\text { Error } \mathbf{f}_{\mathbf{R} .3} \\
6.75 \%\end{array}$} & \multirow{3}{*}{$\begin{array}{r}\text { Error } \mathbf{f}_{\mathbf{R}} \\
6.44 \%\end{array}$} \\
\hline \multirow{2}{*}{ 20-05ST-50/67 } & Exp. & & & & & & & & \\
\hline & Predicted & & & & 3.71 & & & & \\
\hline \multirow{2}{*}{$20-1 \mathrm{ST}-50 / 67$} & Exp. & 5.48 & 5.89 & 5.77 & 5.28 & \multirow{2}{*}{$13.04 \%$} & \multirow{2}{*}{$10.61 \%$} & \multirow{2}{*}{$6.85 \%$} & \multirow{2}{*}{$6.90 \%$} \\
\hline & Predicted & 6.30 & 6.59 & 6.19 & 5.68 & & & & \\
\hline \multirow{2}{*}{$20-05 \mathrm{ST}-33 / 60$} & Exp. & 3.06 & 3.07 & 3.02 & 2.86 & \multirow{2}{*}{$11.21 \%$} & \multirow{2}{*}{$13.94 \%$} & \multirow{2}{*}{$15.64 \%$} & \multirow{2}{*}{$17.62 \%$} \\
\hline & Predicted & 3.44 & 3.56 & 3.58 & 3.47 & & & & \\
\hline \multirow{2}{*}{$20-1 \mathrm{ST}-33 / 60$} & Exp. & 5.73 & 5.58 & 5.07 & 4.57 & \multirow{2}{*}{$6.02 \%$} & \multirow{2}{*}{$12.75 \%$} & \multirow{2}{*}{$15.03 \%$} & \multirow{2}{*}{$15.80 \%$} \\
\hline & Predicted & 6.10 & 6.39 & 5.97 & 5.43 & & & & \\
\hline \multirow{2}{*}{$20-05 \mathrm{ST}-33 / 44$} & Exp. & 2.52 & 2.75 & 2.74 & 2.63 & \multirow{2}{*}{$26.66 \%$} & \multirow{2}{*}{$47.71 \%$} & \multirow{2}{*}{$45.95 \%$} & \multirow{2}{*}{$40.61 \%$} \\
\hline & Predicted & 1.99 & 1.86 & 1.88 & 1.87 & & & & \\
\hline $201 \mathrm{CT} 23 / 44$ & Exp. & 4.74 & 5.01 & 4.77 & 4.28 & & & & \\
\hline $20-151-33 / 44$ & Predicted & 4.64 & 4.69 & 4.27 & 3.83 & $2.05 \%$ & $6.81 \%$ & $11.55 \%$ & $11.60 \%$ \\
\hline & Exp. & 5.52 & 6.48 & 6.73 & 6.40 & & $757 \%$ & $259 \%$ & \\
\hline $40-05 \mathrm{~S} 1-50 / 6 /$ & Predicted & 6.23 & 7.01 & 6.91 & 6.41 & $11.29 \%$ & $1.5 \%$ & $2.59 \%$ & $0.23 \%$ \\
\hline & Exp. & 8.95 & 9.84 & 9.24 & 8.65 & & & & \\
\hline $40-151-50 / 67$ & Predicted & 8.88 & 9.83 & 9.30 & 8.38 & $0.74 \%$ & $0.08 \%$ & $0.61 \%$ & $3.21 \%$ \\
\hline & Exp. & 6.17 & 6.68 & 6.54 & 6.06 & $581 \%$ & $169 \%$ & $124 \%$ & \\
\hline $40-05 S 1-33 / 60$ & Predicted & 5.83 & 6.57 & 6.45 & 5.97 & $5.81 \%$ & $1.69 \%$ & & \\
\hline & Exp. & 9.42 & 10.66 & 9.96 & 8.44 & & & & \\
\hline $40-151-33 / 60$ & Predicted & 8.70 & 9.67 & 9.11 & 8.16 & $8.27 \%$ & $10.28 \%$ & $9.38 \%$ & $3.44 \%$ \\
\hline & Exp. & 3.66 & 3.88 & 3.75 & 3.54 & & & & \\
\hline $40-05 S 1-33 / 44$ & Predicted & 3.99 & 4.38 & 4.30 & 3.97 & $8.3 / \%$ & $11.35 \%$ & $12.63 \%$ & $10.82 \%$ \\
\hline & Exp. & 5.82 & 6.31 & 5.94 & 5.46 & & & & \\
\hline $40-1 S T-33 / 44$ & Predicted & 6.41 & 6.91 & 6.40 & 5.68 & $9.17 \%$ & $8.69 \%$ & $7.26 \%$ & $3.91 \%$ \\
\hline
\end{tabular}

As can be seen in Table 4, the results obtained with the equations showed an average error of $10 \%$, when compared to the average value obtained experimentally. Although the error was relatively high, these equations can serve as an initial reference for the residual resistances that will be achieved based on the characteristics of the SFRSCC that will be produced. However, new tests need to be carried out to reduce this margin of error, so the application of the equations become more technically practicable. An exception was the concrete 20-05ST-33/44, for which the equation did not show a good fit, with errors reaching almost $50 \%$. 
To validate the equations, residual flexural strength estimates were made with data from the Venkateshwaran et al. [12], to verify whether the equations were applicable for other concretes and other materials. The compressive strength of concrete mix and the fibers used by Venkateshwaran et al. [12] in their research are described in Table 5.

Table 5. Properties of hooked steel fiber and compressive strength of concretes mix used by Venkateshwaran et al. [12].

\begin{tabular}{cccccc}
\hline Concrete Mixture & $f_{c^{\prime}}[\mathbf{M P a}]$ & $\mathbf{I}[\mathbf{m m}]$ & $\mathbf{d}[\mathbf{m m}]$ & $\mathbf{l} / \mathbf{d}$ & \multicolumn{1}{c}{ Fiber volume content $(\mathbf{\%})$} \\
\hline M32 & 38.60 & 60 & 0.90 & 66.67 & 0.25 \\
\hline M34 & 37.30 & 60 & 0.90 & 66.67 & 0.50 \\
\hline M36 & 36.00 & 60 & 0.90 & 66.67 & 0.75 \\
\hline M38 & 41.10 & 60 & 0.90 & 66.67 & 1.00 \\
\hline M42 & 38.90 & 60 & 0.90 & 66.67 & 0.25 \\
\hline M44 & 39.70 & 60 & 0.90 & 66.67 & 0.50 \\
\hline M46 & 38.10 & 60 & 0.90 & 66.67 & 0.75 \\
\hline M48 & 39.70 & 60 & 0.90 & 66.67 & 1.00 \\
\hline
\end{tabular}

Based on the comparison between the results found experimentally by Venjareshwaran et al. [12] and the results obtained with the equations proposed in this work, using the fibers and concretes described in Table 5 , it was possible to verify that the equations showed relatively high errors. However, despite the errors reaching up to $20 \%$, the equations showed that they can serve as a reference for the residual resistances that will be achieved. New tests need to be carried out, in order to optimize the coefficients of the equations, minimizing the errors found.

However, as can be seen in the M32 and M42 concretes mix with $0.25 \%$ fiber content, a volume outside the interval to which the regression was performed to obtain the equations $(0.50 \%$ to $1.00 \%)$, errors were very high, reaching almost $50 \%$, overestimating the value of residual flexural strength. The equations were well suited to estimate residual flexural strength when the variation in fiber volume is within the limits of the database used to perform the regression. As the compressive strength and the fiber aspect ratio used by Venjareshwaran et al. [12] were similar to those used in this research, shown in Table 6, it is not possible to draw large conclusions regarding the effects of a compressive strength and fiber resistance with aspect ratio outside the limits of the database.

Table 6. Comparison between the values of residual flexural strengths found experimentally by Venkateshwaran et al. [12] and the predicted by the equations obtained in this work.

\begin{tabular}{|c|c|c|c|c|c|c|c|c|c|}
\hline \multirow{2}{*}{\multicolumn{2}{|c|}{ Concrete Mix }} & \multicolumn{8}{|c|}{$\begin{array}{c}\text { Experimental data obtained by Venkateshwaran et al. (2018) vs. Values predicted by the } \\
\text { proposed equations }\end{array}$} \\
\hline & & $\begin{array}{c}\mathbf{f R}_{\mathrm{R} .1} \\
{[\mathrm{MPa}]}\end{array}$ & Error f $f_{R .1}$ & $\begin{array}{c}\mathbf{f}_{\mathrm{R} .2} \\
{[\mathrm{MPa}]}\end{array}$ & Error $f_{R .2}$ & $\begin{array}{c}\mathbf{f}_{\mathbf{R} .3} \\
{[\mathrm{MPa}]}\end{array}$ & Error $f_{R .3}$ & $\begin{array}{c}\mathbf{f}_{\mathbf{R} .4} \\
{[\mathrm{MPa}]}\end{array}$ & Error $f_{R .4}$ \\
\hline \multirow{2}{*}{ M32 } & Exp. & 2.38 & \multirow{2}{*}{$42.66 \%$} & 2.69 & \multirow{2}{*}{$45.00 \%$} & 2.76 & \multirow{2}{*}{$44.92 \%$} & 2.74 & \multirow{2}{*}{$45.17 \%$} \\
\hline & Predicted & 4.15 & & 4.89 & & 5.01 & & 5.00 & \\
\hline \multirow{2}{*}{ M34 } & Exp. & 5.29 & \multirow{2}{*}{$0.68 \%$} & 6.56 & \multirow{2}{*}{$7.32 \%$} & 7.00 & \multirow{2}{*}{$16.18 \%$} & 6.98 & \multirow{2}{*}{$19.92 \%$} \\
\hline & Predicted & 5.33 & & 6.11 & & 6.03 & & 5.82 & \\
\hline \multirow{2}{*}{ M36 } & Exp. & 7.29 & \multirow{2}{*}{$12.17 \%$} & 8.25 & \multirow{2}{*}{$12.54 \%$} & 8.04 & \multirow{2}{*}{$14.27 \%$} & 7.82 & \multirow{2}{*}{$17.76 \%$} \\
\hline & Predicted & 6.50 & & 7.33 & & 7.04 & & 6.64 & \\
\hline \multirow{2}{*}{ M38 } & Exp. & 6.82 & \multirow{2}{*}{$18.99 \%$} & 9.39 & \multirow{2}{*}{$1.02 \%$} & 9.51 & \multirow{2}{*}{$6.28 \%$} & 9.17 & \multirow{2}{*}{$11.23 \%$} \\
\hline & Predicted & 8.42 & & 9.49 & & 8.95 & & 8.24 & \\
\hline \multirow{2}{*}{ M42 } & Exp. & 3.26 & \multirow{2}{*}{$22.11 \%$} & 4.62 & \multirow{2}{*}{$6.38 \%$} & 4.26 & \multirow{2}{*}{$15.70 \%$} & 3.56 & \multirow{2}{*}{$29.28 \%$} \\
\hline & Predicted & 4.19 & & 4.93 & & 5.05 & & 5.03 & \\
\hline \multirow{2}{*}{ M44 } & Exp. & 4.89 & \multirow{2}{*}{$12.75 \%$} & 6.67 & \multirow{2}{*}{$3.21 \%$} & 6.47 & \multirow{2}{*}{$1.70 \%$} & 5.42 & \multirow{2}{*}{$11.33 \%$} \\
\hline & Predicted & 5.60 & & 6.46 & & 6.36 & & 6.11 & \\
\hline \multirow{2}{*}{ M46 } & Exp. & 6.16 & \multirow{2}{*}{$8.71 \%$} & 8.11 & \multirow{2}{*}{$6.11 \%$} & 7.21 & & 6.08 & \\
\hline & Predicted & 6.75 & & 7.64 & & 7.34 & $1.72 \%$ & 6.90 & $11.90 \%$ \\
\hline M48 & Exp. & 9.08 & & 9.70 & & 8.94 & & 7.56 & \\
\hline M48 & Predicted & 8.26 & $9.93 \%$ & 9.29 & $4.44 \%$ & 8.76 & $2.09 \%$ & 6.90 & $9.54 \%$ \\
\hline
\end{tabular}


In order to verify if the equations obtained in this work were able to estimate the residual flexural strengths in SFRSCC with compressive strengths outside the range of this work's database, the predicted residual flexural strengths were calculated using the equations obtained in this paper for some of the concretes produced in Lameiras [26], shown in Table 7, and compared with the experimental results he obtained.

Table 7. Properties of hooked steel fiber and compressive strength of concretes mix used by Lameiras [26].

\begin{tabular}{cccccc}
\hline Concrete Mixture & $f_{c}[\mathbf{M P a}]$ & $\mathbf{l}[\mathbf{m m}]$ & $\mathbf{d}[\mathbf{m m}]$ & \multicolumn{1}{l}{$\mathbf{d}$} & \multicolumn{2}{c}{ Fiber volume content $(\mathbf{\%})$} \\
\hline 10 & 45.60 & 35 & 0.55 & 63.64 & 0.75 \\
\hline 11 & 56.39 & 35 & 0.55 & 63.64 & 0.75 \\
\hline 12 & 61.23 & 35 & 0.55 & 63.64 & 0.75 \\
\hline 13 & 61.94 & 35 & 0.55 & 63.64 & 0.75 \\
\hline 16 & 60.66 & 35 & 0.55 & 63.64 & 0.75 \\
\hline 17 & 63.46 & 35 & 0.55 & 63.64 & 0.75 \\
\hline 18 & 54.81 & 35 & 0.55 & 63.64 & 0.75 \\
\hline
\end{tabular}

Based on the results described in Table 8, it is possible to observe that none of the concretes fits well in the equations found in this work, showing that they are not applied satisfactorily in concretes with compressive strength outside the range studied in this research, which was $20 \mathrm{MPa}$ at $40 \mathrm{MPa}$. Mixture 10 presented compressive strength close to the values used in the regressions that provided the equations. However, it also presented high errors, on average of $15 \%$, although smaller when compared to the other concrete mixtures produced by Lameiras [26].

Table 8. Comparison between the values of residual flexural strengths found experimentally by Lameiras [26] and with predicted by the equations.

\begin{tabular}{|c|c|c|c|c|c|c|c|c|c|}
\hline & \multirow{2}{*}{ Concrete Mix } & \multicolumn{8}{|c|}{$\begin{array}{c}\text { Experimental data obtained by Lameiras et al. (2015) vs. Values predicted by the proposed } \\
\text { equations }\end{array}$} \\
\hline & & $\begin{array}{c}\mathbf{f}_{\mathrm{R} .1} \\
{[\mathrm{MPa}]}\end{array}$ & Error $f_{R .1}$ & $\begin{array}{c}\mathbf{f}_{\mathrm{R} .2} \\
{[\mathrm{MPa}]}\end{array}$ & Error $\mathbf{f}_{R .2}$ & $\begin{array}{c}\mathbf{f}_{\mathrm{R} .3} \\
{[\mathrm{MPa}]}\end{array}$ & Error $\mathbf{f}_{R .3}$ & $\begin{array}{c}\mathbf{f}_{\mathrm{R} .4} \\
{[\mathrm{MPa}]}\end{array}$ & Error f fR.4 \\
\hline \multirow{2}{*}{10} & Exp. & 9.21 & \multirow{2}{*}{$24.95 \%$} & 8.11 & \multirow{2}{*}{$4.03 \%$} & 6.82 & \multirow{2}{*}{$15.84 \%$} & 5.70 & \multirow{2}{*}{$24.35 \%$} \\
\hline & Predicted & 7.37 & & 8.45 & & 8.10 & & 7.54 & \\
\hline \multirow{2}{*}{11} & Exp. & 8.22 & \multirow{2}{*}{$2.84 \%$} & 7.13 & \multirow{2}{*}{$27.40 \%$} & 5.42 & \multirow{2}{*}{$42.46 \%$} & 4.13 & \multirow{2}{*}{$52.41 \%$} \\
\hline & Predicted & 8.46 & & 9.82 & & 9.42 & & 8.68 & \\
\hline \multirow{2}{*}{12} & Exp. & 7.44 & \multirow{2}{*}{$16.55 \%$} & 6.67 & \multirow{2}{*}{$35.81 \%$} & 5.52 & \multirow{2}{*}{$44.63 \%$} & 4.61 & \multirow{2}{*}{$49.64 \%$} \\
\hline & Predicted & 8.91 & & 10.39 & & 9.97 & & 9.15 & \\
\hline \multirow{2}{*}{13} & Exp. & 6.82 & \multirow{2}{*}{$24.05 \%$} & 6.25 & \multirow{2}{*}{$40.33 \%$} & 5.38 & \multirow{2}{*}{$46.45 \%$} & 4.69 & \multirow{2}{*}{$49.15 \%$} \\
\hline & Predicted & 8.98 & & 10.47 & & 10.05 & & 9.22 & \\
\hline \multirow{2}{*}{16} & Exp. & 6.67 & \multirow{2}{*}{$24.74 \%$} & 5.97 & \multirow{2}{*}{$42.18 \%$} & 5.26 & \multirow{2}{*}{$46.90 \%$} & 4.54 & \multirow{2}{*}{$50.10 \%$} \\
\hline & Predicted & 8.86 & & 10.33 & & 9.91 & & 9.10 & \\
\hline \multirow{2}{*}{17} & Exp. & 8.39 & \multirow{2}{*}{$7.99 \%$} & 7.59 & \multirow{2}{*}{$28.71 \%$} & 6.52 & \multirow{2}{*}{$36.17 \%$} & 5.66 & \multirow{2}{*}{$39.58 \%$} \\
\hline & Predicted & 9.12 & & 10.65 & & 10.21 & & 9.37 & \\
\hline \multirow{2}{*}{18} & Exp. & 8.36 & \multirow{2}{*}{$0.63 \%$} & 7.47 & \multirow{2}{*}{$22.42 \%$} & 6.40 & $3070 \%$ & 5.59 & 34370 \\
\hline & Predicted & 8.31 & & 9.63 & & 9.24 & $30.10 \%$ & 8.52 & $34.3 / \%$ \\
\hline 10 & Exp. & 6.62 & \% 270 & 6.01 & & 5.16 & & 4.55 & \\
\hline 19 & Predicted & 9.24 & $28.37 \%$ & 10.80 & $44.36 \%$ & 10.36 & $50.21 \%$ & 8.52 & $46.58 \%$ \\
\hline
\end{tabular}

Analysing the concretes produced by Venjareshwaran et al. [12] and Lameiras [26], it is possible to verify that the equations are satisfactorily valid when used in concretes fiber content and compressive strength within those in the range of the SFRSCCs studied in this paper. That is, for fiber contents from $0.00 \%$ to $1.00 \%$, in SFRSCC with 
compressive strength from $20 \mathrm{MPa}$ to $40 \mathrm{MPa}$. When the compressive strength and fiber content were outside these ranges, the errors found in the experimental and analytical comparison were very high.

Analysing the comparison of the predicted residual strengths with the obtained experimentally for the concretes produced by Venjareshwaran et al. [12] and Lameiras [26], it is possible to verify that, when the equations are used in the content of concrete fibers and in the compressive strength within the ranges of the SFRSCCs studied in this work, despite relatively high errors, the equations provided an indication of the residual resistances that have been reached. That is, for fiber contents from $0.50 \%$ to $1.00 \%$, in the SFRSCC with compressive strength from $20 \mathrm{MPa}$ to $40 \mathrm{MPa}$, the equations can be used to estimate the residual strength of concrete based on the materials used in the SFRSCC. However, for a more technical and rational application, further studies need to be carried out in order to optimize the equations and reduce errors.

\section{CONCLUSIONS}

An experimental study was performed to examine the direct residual flexural strengths of Steel Fiber Reinforced Self Compacting Concrete specimens with two compressive strengths, 20 and $40 \mathrm{MPa}$, and fiber volume factions, $0.50 \%$ and $1,00 \%$. The experimental program included tests of 96 specimens: 48 small beams for the three point bending tests and 48 cylindrical specimens for compressive strength test. Variables of the experimental program were the type of fibers, the fiber volume content and concrete strengths. The main conclusions were:

1. Regarding the behavior of concrete in the hardened state, small reductions in compressive strength were observed in $40 \mathrm{MPa}$ concrete with ST-33/44 fibers.

2. The fibers ST-33/60 and ST-50/67 were the ones that led to the greatest increases in residual flexural strength of SFRSCC. This can be explained by the larger form factor of the two fibers (60 and 67), respectively. In the case of the ST-50/67 fiber, the importance of the fiber length can still be emphasized, ensuring greater anchorage in the concrete and, consequently, greater efficiency. The worst result was found for the concrete with ST-33/44 fiber, which can be explained by the fact that the fiber has a shorter length and aspect ratio (44).

3. The proposed equations, obtained based on the experimental data of this work to determine the residual resistance of the SFRSCC, reached an average error of $10 \%$ in relation to the experimental results. The errors were relatively high; however, the equations can be adopted to initially estimate residual resistances. However, studies seeking to minimize errors must be carried out.

4. When compared to the results obtained by Venkashwaran et al. [12] it was found that, when the variables (matrix strength, fiber geometric characteristics and fiber volume) are similar to those used in this work, with variations within the ranges adopted in this research, the estimated results had average errors around $10 \%$.

5. When compared to the results obtained by Lameiras [26], it was found that, when the fiber content and the compressive strength of the matrix were outside the varied limits in this study, the errors were high, and it is not possible to use the equations of this work to estimate the residual strengths of these concretes.

\section{REFERENCES}

[1] S. Grünewald, Performance-Based Design of Self-Compacting Fibre Reinforced Concrete. Delft: Delft Univ. Technol., 2004.

[2] L. Ferrara and A. Meda, "Relationships between fibre distribution, workability and the mechanical properties of SFRC applied to precast roof elements," Mater. Struct., vol. 39, no. 4, pp. 411-420, 2007.

[3] A. C. Barros, “Avaliação do comportamento de vigas de concreto auto-adensável reforçado com fibras de aço,” M.S. thesis, Univ. Fed. Alagoas, Maceió, 2009.

[4] R. Lameiras, J. Barros, I. B. Valente, and M. Azenha, "Development of sandwich panels combining fibre reinforced concrete layers and fibre reinforced polymer connectors. Part I: conception and pull-out tests," Compos. Struct., vol. 105, pp. 446-459, 2013.

[5] J. Hedebratt and J. Silfwerbrand, "Full-scale test of a pile supported steel fibre concrete slab," Mater. Struct., vol. 47, no. 4, pp. 647666,2014

[6] H. Salehian and J. A. Barros, "Assessment of the performance of steel fibre reinforced self-compacting concrete in elevated slabs," Cement Concr. Compos., vol. 55, pp. 268-280, 2015.

[7] H. Ahmad, "Steel Fibre Reinforced Self-Compacting Concrete (SFRSC) performance in slab application: a review,"AIP Conf. Proc., vol. 1774, 030024, 2016.

[8] D. Y. Yoo, Y.-S. Yoon, and N. Banthia, "Predicting the post-cracking behavior of normal- and high-strength steel-fiber-reinforced concrete beams," Constr. Build. Mater., vol. 93, pp. 477-485, 2015.

[9] K. Mak and A. Fam, "Freeze-thaw cycling effect on tensile properties of unidirectional flax fiber reinforced polymers," Compos., Part B Eng., vol. 174, pp. 106960, 2019, http://dx.doi.org/10.1016/j.compositesb.2019.106960. 
[10] C. Lin, O. Kayali, E. V. Morozov, and D. J. Sharp, "Influence of fibre type on flexural behaviour of self-compacting fibre reinforced cementitious composites," Cement Concr. Compos., vol. 51, pp. 27-37, 2014.

[11] J. H. Lee, B. Cho, and E. Choi, "Flexural capacity of fiber reinforced concrete with a consideration of concrete strength and fiber contente," Constr. Build. Mater., vol. 138, pp. 222-231, 2017.

[12] A. Venkateshwaran, K. H. Tan, and Y. Li, Residual Flexural Strengths of Steel Fiber Reinforced Concrete with Multiple Hooked-End Fibers. Lausanne: International Federation for Structural Concrete, 2018.

[13] W. Abbass, M. I. Khan, and S. Mourad, "Evaluation of mechanical properties of steel fiber reinforced concrete with different strengths of concrete," Constr. Build. Mater., vol. 168, pp. 556-569, 2018.

[14] J. Domski and J. Katzer, "Comprehensive approach to evaluation of mechanical properties of waste aggregate concrete reinforced by steel fiber," Struct. Concr., vol. 21, no. 1, pp. 428-436, 2020, http://dx.doi.org/10.1002/suco.201800271.

[15] International Union of Laboratories and Experts in Construction Materials, Systems and Structures, "Recommendations of RILEM TC 162-TDF: Test and design methods for steel fibre reinforced concrete Design of steel fibre reinforced concrete using the sigmaepsilon method: principles and applications," Mater. Struct., vol. 35, no. 249, pp. 262-278, 2002.

[16] F. De Larrard and T. Sedran. "Formation à BétonlabPro 3: 15 leçonst." IFSTTAR. https://betonlabpro.ifsttar.fr/betonlabpro/formation-a-betonlabpro-3-didacticiel/ (accessed Mar. 5, 2016).

[17] Associação Brasileira de Normas Técnicas, Concreto Autoadensável, NBR 15823, 2017.

[18] Associação Brasileira de Normas Técnicas, Concreto - Ensaio de Compressão de Corpos de Prova Cilindricos, NBR $5739,2018$.

[19] J. F. Correal and C. A. Herrána, "Performance of hybrid fiber-reinforced concrete for low-rise housing with thin walls," Constr. Build. Mater., vol. 185, pp. 519-529, 2018.

[20] H. Hu, Z. Wang, F. P. Figueiredo, P. Papastergiou, M. Guadagnini, and K. Pilakoutas, "Postcracking tensile behavior of blended steel fiber-reinforced concrete," Struct. Concr., vol. 20, no. 2, pp. 707-719, 2019.

[21] N. Banthia, F. Majdzadeh, J. Wu, and V. Bindiganavile, "Fiber synergy in Hybrid Reinforced Concrete (HyFRC) in flexure and direct shear," Cement Concr. Compos., vol. 48, pp. 91-97, 2014.

[22] J. Carrillo, J. A. Pincheira, and S. M. Alcocer, "Behavior of low-rise, steel fiber-reinforced concrete thin walls under shake table excitations," Eng. Struct., vol. 138, no. 1, pp. 146-158, 2017.

[23] A. Conforti, F. Minelli, G. Plizzari, and G. Tibert, "Comparing test methods for the mechanical characterization of fiber reinforced concrete," Struct. Concr., vol. 19, no. 3, pp. 656-669, 2017.

[24] W. Abbass, M. I. Khan, and S. Mourad, "Evaluation of mechanical properties of steel fiber reinforced concrete with different strengths of concrete," Constr. Build. Mater., vol. 168, pp. 556-569, 2018.

[25] A. K. H. Kwan and S. H. Chu, "Direct tension behaviour of steel fibre reinforced concrete measured by a new test method," Eng. Struct., vol. 176, no. 1, pp. 324-336, Dec 2018., http://dx.doi.org/10.1016/j.engstruct.2018.09.010.

[26] R. M. Lameiras, "Sandwich structural panels comprising thin-walled SFRSCC and GFRP connectors: from material features to structural behaviour," Ph.D. dissertation, Univ. Minho, 2015.

Author contributions: MGC: writing, conceptualization, methodology, experimental program data curation, formal analysis, and paper review; RML: methodology, conceptualization, funding acquisition, supervision, formal analysis, whiting, and paper review; VMSC: methodology, conceptualization funding acquisition, supervision, formal analysis and paper review.

Editors: Bernardo Tutikian, José Luiz Antunes de Oliveira e Sousa, Guilherme Aris Parsekian. 